\title{
Urinary Biotinidase and Alanine Excretion in Patients with Insulin-Dependent Diabetes Mellitus ${ }^{1}$ )
}

\author{
Elena A. Terentyeva ${ }^{1}$, Kou Hayakawa ${ }^{1}$, Ayako Tanae ${ }^{2}$, Noriyuki Katsumata ${ }^{1}$, Toshiaki Tanaka ${ }^{1}$ and Itsuro Hibi ${ }^{2}$ \\ 1 Endocrine and Metabolism Research Laboratory, National Children's Medical Research Center \\ 2 Department of Endocrinology and Metabolism, National Children's Hospital \\ Taishido, Setagaya-ku, Tokyo, Japan
}

\begin{abstract}
Summary: Twenty-four-hour urine specimens from 21 juvenile insulin-dependent diabetics and 10 healthy controls were compared with respect to biotinidase activity and alanine content. Urinary biotinidase activity was analysed by a newly developed high-performance liquid chromatography (HPLC) method. It was found that the excretion of biotinidase in urine was elevated in diabetics $(7.02 \mathrm{mU} / \mathrm{d} ; \mathrm{p}<0.005)$ as compared with controls (not detectable). Alanine excretion was also found to increase $(p<0.01)$ in diabetics. Biotinidase excretion in diabetics was correlated with alanine excretion $(\mathrm{rS}=0.667 ; \mathrm{p}<0.01)$, but not with protein, albumin or $\mathrm{N}$-acetyl- $\beta$-glucosaminidase excretion. The simultaneous elevation of urinary biotinidase and alanine excretion in juvenile diabetics suggests that changes in kidney metabolism arise in the early stages of diabetes.
\end{abstract}

\section{Introduction}

Diabetic nephropathy develops particularly often among patients with juvenile onset diabetes mellitus, in which the cumulative risk of nephropathy is about $30-40 \%$.

Morphological changes in the capillary basement membrane and microalbuminuria are readily detectable in the kidney of early diabetic nephropathy patients $(1-3)$. The current chemical standard for detecting nephropathy is micro-albuminuria (4). Decreased contents of cystine and sialic acid have been reported in diabetic kidney (5). Changes in the renal handling of some amino acids in diabetic kidney have also been suggested (6).

Biotinidase (EC 3.5.1.12), an amidase that hydrolyses biocytin, is present in the microsome fraction (endoplasmic reticulum) of guinea pig and rat livers $(7,8)$, and the activity of this enzyme in pig and rat has been shown to be highest in the kidneys $(8-10)$. This enzyme from human serum also recognizes lipoyl-amide compounds $(11,12)$ and enkephalin (13). From studies on biotinidase deficiency (14), it has been suggested that one of the major biological roles of biotinidase is to recycle biotin. Studies on patients with biotinidase deficiency (15) also indicate that kidney biotinidase functions in the re-uptake of biotin and biocytin. Elevated alanine levels in urine of biotinidase deficient patients have also been recently reported (16). Biotinidase has been shown to be detectable in various renal diseases (17). Therefore,

1) A part of this work was presented at the 20th annual meeting of the international society for pediatric and adolescent diabetes, Atami-city, Shizuoka, Japan, November, 1994. we compared biotinidase and alanine excretion in the urine of diabetics and controls in order to clarify the role of biotinidase in the kidney.

\section{Materials and Methods}

Patients

Patients $(n=21$, female $n=12$, male $n=9$ ) with juvenile onset diabetes mellitus: 17 outpatient and 4 hospitalized cases from the National Children's Hospital (Tokyo, Japan).

Clinical profiles in 21 patients with insulin-dependent diabetes mellitus: Age, 13.0 years (median), 3-26 years (range); Duration of insulin-dependent diabetes mellitus, 5.0 years (median), $0-22$ years (range); Blood pressure, systolic 14.5 \pm 2.13 (mean $\pm \mathrm{SD}$ ) $\mathrm{kPa}$, diastolic $8.53 \pm 1.60 \mathrm{kPa}$; Treatment: Insulin requirement, $53.6 \pm 35.4 \mathrm{U} / \mathrm{d}, 38 \pm 19 \mathrm{U} / \mathrm{m}^{2}$ body surface area; Diet, $6750-$ $8400 \mathrm{~kJ} / \mathrm{d}$ (1600-2000 kcal/d); Laboratory findings: Serum creatinine, $45.8 \pm 3.8 \mu \mathrm{mol} / \mathrm{l}$; blood urea nitrogen $2.30 \pm 0.566 \mathrm{mmol} / \mathrm{l}$; total cholesterol, $4.58 \pm 0.698 \mathrm{mmol} / \mathrm{l}$; HDL-cholesterol, 1.55 $\pm 0.388 \mathrm{mmol} / 1$; triacylglycerols, $850 \pm 420 \mathrm{mg} / \mathrm{l}$; fructosamine, $3.16 \pm 0.82 \mu \mathrm{mol} / \mathrm{l} ; \mathrm{HbA}_{1}, 10.18 \pm 2.1 \%, \mathrm{HbA}_{1 \mathrm{c}}$ (HPLC method using polymer gel), $8.07 \pm 1.9 \%$; volume of urine, median $1.280 \mathrm{l}$, range $0.620-2.200 \mathrm{l}$; urine glucose, $15.49 \pm 19.88 \mathrm{~g} / \mathrm{d}$; creatinine clearance, $2.145 \pm 1.332 \mathrm{ml} / \mathrm{s} \times \mathrm{m}^{2}$ body surface area. All of the diabetic group received a diabetic diet and insulin, produced in USA (Lilly) and Denmark (Novo Nordisk). Insulin was injected 2-4 times per day but one of the hospitalized patients received pump insulin injection. In addition, one diabetic patient was treated with steroid and another with thyroxin for to concomitant diseases. Preproliferative diabetic retinopathy was marked in 3 patients, 1 had transitional proteinuria with 22 years of duration, 1 had bulimia. Concomitant diseases: nephrosis, one patient; thyroid disturbance, one patient; hand abnormality, one patient; Down's syndrome, one patient.

Healthy controls

Healthy volunteers $(n=10$; female 4 , male 6$)$ of the institute. All the volunteers were free from anomalies or pathology of kidneys, urinary tract infection, and other acute infections. Characteristics 
of healthy controls: Age, 12.0 years (median), 7-50 years (range); volume of urine, 0.8851 (median), 0.624-2.961 l (range).

\section{Specimens}

Twenty-four-hour urine samples were collected from diabetic patients. After measuring the total volume, an aliquot was filtered (Ekicrodisc 13; $200 \mathrm{~nm}$ pore size Versapor, Gelman Sciences Japan, Ltd., Tokyo, Japan) and stored at $-80^{\circ} \mathrm{C}$.

\section{Chemicals and reagents}

Biotinyl-6-aminoquinoline and biocytin were purchased from Sigma Chemical Co., St. Louis, MO, USA. 6-Aminoquinoline was from Aldrich Chemical Co., Milwaukee, WI, USA. L-Amino acid standards were from Takara Kohsan Co., Ltd., Tokyo, Japan. Polyoxyethylene (20) cetyl ether (Brij-58), glycerol, o-phthalaldehyde and 1,2-diamino-4,5-methylenedioxybenzene dihydrochloride were from Wako Pure Chemical Co., Osaka, Japan. Sialic acid (N-acetylneuraminic acid) was from Nacalai Tesque, Inc., Kyoto, Japan. Develosil ODS-10 (octadecylsilane-bonded silica gel for high-performance liquid chromatography) was from Nomura Chemical Co., Seto, Aichi, Japan.

\section{Biotinidase}

Biotinidase activity in urine was measured by the high-performance liquid chromatography (HPLC) fluorometric method (17) using biotinyl-6-aminoquinoline as substrate. Biotinyl-6-aminoquinoline was dissolved at $0.044 \mathrm{mmol} / 1(16.3 \mathrm{mg} / \mathrm{l})$ in $0.1 \mathrm{~mol} / \mathrm{l}$ sodium phosphate buffer ( $\mathrm{pH} 7.0)$ containing $1 \mathrm{mmol} / 1(452 \mathrm{mg} / \mathrm{l})$ $\mathrm{Na}$-EDTA and $10 \mathrm{mmol} / 1(781 \mathrm{mg} / \mathrm{l})$ 2-mercaptoethanol. Substrate in $0.090 \mathrm{ml}$ of the reaction buffer was mixed with $0.010 \mathrm{ml}$ of enzyme solution. Thus, the reaction mixture $(0.100 \mathrm{ml})$ contained $1.468 \mu \mathrm{g}(3.96 \mathrm{nmol})$ of biotinyl-6-amino-quinoline, $0.040 \mathrm{mg}$ of EDTA and $0.070 \mathrm{mg}$ of 2-mercaptoethanol. The reaction was allowed to proceed for an appropriate time at $37^{\circ} \mathrm{C}$, then stopped by adding $0.200 \mathrm{ml}$ of methanol; the reaction mixture was diluted three-fold with methanol to precipitate the enzyme proteins. After centrifugation and deproteinization at $1500 \mathrm{~g}$ for $15 \mathrm{~min}$, a portion $(0.010 \mathrm{ml})$ of the clear supernatant was injected into the HPLC system. The HPLC system for biotinidase assay consisted of a model 600E HPLC pump (Waters Associates, Inc., Milford, MA, USA), an injector (model U6K), a reversed-phase column (octade-

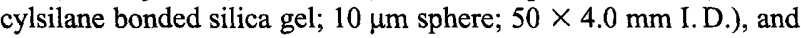
a detector (model F-3000 fluorescence spectrophotometer, Hitachi, Tokyo, Japan). The product 6 -aminoquinoline was separated by the reversed-phase column, and measured at an excitation wavelength of $350 \mathrm{~nm}$ and an emission wavelength of $550 \mathrm{~cm}$. The rate of release of 6-aminoquinoline from substrate was calculated as previously described (17).

Biotinidase activity was also determined by measuring the release of $L$-lysine from biocytin $(0.152 \mathrm{mmol} / \mathrm{l})$, using an HPLC amino acid analyser according to the method described previously (13).

An enzyme unit was defined according to Ochoa et al. (18), i.e. one unit was the amount of enzyme catalysing the release of $1 \mathrm{nmol}$ of 6-aminoquinoline per minute at $37^{\circ} \mathrm{C}$ from biotinyl-6aminoquinoline or $1 \mathrm{nmol}$ of lysine from biocytin. Specific activity was expressed as units per mg of (urinary) protein. The values were multiplied by 1000 in order to obtain International Units $(1 \mathrm{U}$ $=1 \mu \mathrm{mol} / \mathrm{min}$ )

\section{Urinary proteins and albumin determinations}

Proteins and albumin in the urine were determined by sensitive high-performance gel-permeation chromatography as described previously (19).

\section{Free amino acid measurements}

Free $L$-amino acids were measured by using an HPLC amino-acid analyser $\left(\mathrm{Na}^{+}\right.$-type) as described previously (20) connected with an autosampler (model AS-100, Bio-Rad, Richmond, CA 94804,
USA). Filtered urine samples were diluted 40 -fold with $0.1 \mathrm{~mol} / 1$ $\mathrm{HCl}$, and a $0.01 \mathrm{ml}$ portion was injected into the HPLC system.

\section{Miscellaneous urine analyses}

Free and total sialic acid was measured by an HPLC-fluorimetric method (21). N-Acetyl- $\beta$-glucosaminidase activity was measured in 12 samples out of 21 patient urines by a photometric method using 6-methyl-2-pyridyl- $\mathrm{N}$-acetyl- $\beta$-glucosamine as substrate (Nittobo Medical Co., Tokyo, Japan). C-peptide was measured in 20 samples out of 21 patient urines by a RIA method (using samples stored at $-80^{\circ} \mathrm{C}$ ).

\section{Statistical analysis}

Non-parametric statistical analysis was performed. Mann-Whitney's $\mathrm{U}$ test was used for assessing the significance of the difference of two groups. Spearman's rank correlation coefficients (rS) were used for estimating correlations between two groups. Calculations were performed on a personal computer (Epson PC-485GR Super, Seiko-Epson Co., Suwa-City, Nagano 392, Japan), using the software: Statflex Lite, Version 2 (J.I. P. Co., Tokyo, Japan). A probability value below 0.01 was considered to be significant.

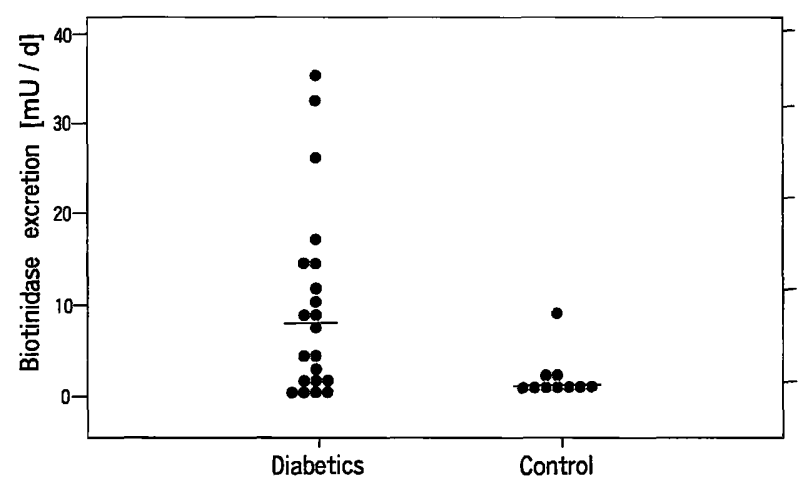

Fig. 1 Urinary 24-hour excretions of biotinidase in patients with insulin-dependent diabetes mellitus $(n=21)$ and in controls $(\mathrm{n}=10)$. Biotinidase activity was determined using biotininyl-6aminoquinoline as substrate, and calculated as described in the Materials and Methods section.

Tab. 1 Differences in biotinidase and free amino acid excretions per day between insulin-dependent diabetes mellitus patients and normal controls.*

\begin{tabular}{|c|c|c|c|}
\hline & $\begin{array}{l}\text { Difference } \\
\text { n-fold }\end{array}$ & $\begin{array}{l}\text { Diabetics } \\
(\mathrm{n}=21) \\
\text { Median } \\
\text { Range }\end{array}$ & $\begin{array}{l}\text { Controls } \\
(\mathrm{n}=10) \\
\text { Median } \\
\text { Range }\end{array}$ \\
\hline Biotinidase $^{a}$ & - & $\begin{array}{l}7.02 \\
0.00-34.2\end{array}$ & $\begin{array}{l}0.00 \\
0.00-10.9\end{array}$ \\
\hline Alanine $^{b}$ & 2.21 -fold & $\begin{array}{l}812 \\
215-1714\end{array}$ & $\begin{array}{l}368 \\
147-895\end{array}$ \\
\hline Valine $^{\mathbf{b}}$ & 1.79-fold & $\begin{array}{l}69.0 \\
0-214\end{array}$ & $\begin{array}{l}38.5 \\
17.5-100\end{array}$ \\
\hline Phenylalanine $^{c}$ & 1.52-fold & $\begin{array}{l}160 \\
0-360\end{array}$ & $\begin{array}{l}105 \\
41-76\end{array}$ \\
\hline Histidine $^{c}$ & 2.10 -fold & $\begin{array}{l}2419 \\
238-4830\end{array}$ & $\begin{array}{l}1152 \\
538-2604\end{array}$ \\
\hline
\end{tabular}

* Biotinidase excretion was expressed as $\mathrm{mU} / \mathrm{d}$. Amino acid excretion was expressed as $\mu \mathrm{mol} / \mathrm{d}$. Significance was calculated from Mann-Whitney's U test. $\left({ }^{\mathrm{a}} \mathrm{p}<0.005 ;{ }^{\mathrm{b}} \mathrm{p}<0.01 ;{ }^{\mathrm{c}} \mathrm{p}<0.05\right)$. 


\section{Results and Discussion}

It was found that $67 \%(14 / 21)$ of patients showed positive or pathological biotinidase excretion as compared to a control level of $10 \%(1 / 10)$; i. e., the cut-off level for negativity was defined as $90 \%$ of controls (fig. 1). As shown in table 1, this elevation was found to be significant $(\mathrm{p}<0.005)$ as estimated by Mann-Whitney's U test. There were no statistically significant differences between the controls and patients with respect to age and sex, according to Mann-Whitney's U test for age and Fisher's exact test for sexes, respectively.

As also shown in figure 2 and table 1 , only alanine and valine excretion were significantly $(\mathrm{p}<0.01)$ increased in diabetic urine. Other amino acids and analytes, such as free sialic acid, total proteins, and albumin were not significantly elevated.

Urinary biotinidase and albumin have similar molecular masses and different characteristics, which are summarized in table 2. Although biotinidase and albumin have similar acidic $\mathrm{pI}$ values, their excretion showed no correlation at all (tab. 3). Biotinidase excretion showed a positive correlation $(\mathrm{rS}=0.667 ; \mathrm{p}<0.01)$ with alanine excretion (tab. 3). Thus, the urines of insulin-dependent diabetes mellitus patients show simultaneous elevations of biotinidase and alanine excretion, which are positively correlated. In the control group, biotinidase excretion $(\mathrm{n}=3)$ was not correlated with alanine excretion.

Normal energy metabolism, as determined by the production and utilization of ATP and NADH, is known to be essential for kidney preservation and transplantation $(22,23)$. It is also known that kidney is the tissue containing the highest biotinidase activity in pig (9). Baumgartner et al. (15) have suggested that kidney biotinidase functions in the reabsorption of biotin and biocytin. The active transport of $L$-alanine in bacteria has been demonstrated using NADH or ascorbate plus phenazine methosulphate as energy sources (24). Therefore, kidney biotinidase and the alanine transport system may be linked through the energy metabolism of the kidney.

Biotinidase excretion into urine is certainly pathophysiological (tab. 1 in 1.c. (19)), although the simultaneous

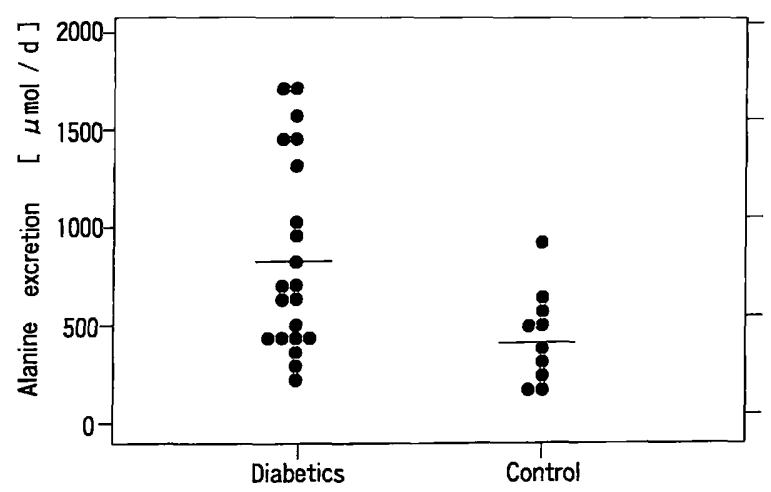

Fig. 2 Urinary 24-hour excretions of alanine in patients with insulin-dependent diabetes mellitus $(n=21)$ and in controls $(\mathrm{n}=10)$. Alanine was determined with an HPLC amino acid analyser as described in the Materials and Methods section.

Tab. 2 Summary of some differences between biotinidase and albumin in urine ${ }^{a}$.

\begin{tabular}{|c|c|c|}
\hline \multirow[t]{2}{*}{ Characteristics } & \multicolumn{2}{|l|}{ Protein } \\
\hline & Biotinidase & Albumin \\
\hline Relative molecular mass & 66000 & 66000 \\
\hline Isoelectric point $(\mathrm{pI})$ & 4.4 & 4.9 \\
\hline Glyco-chain & $\mathrm{O}$-glycoside & - \\
\hline $\begin{array}{l}\text { Subcellular distribution } \\
\text { in tissue }\end{array}$ & $\begin{array}{l}\text { Microsome } \\
\text { (Endoplasmic } \\
\text { reticulum) }\end{array}$ & - \\
\hline Enzyme activity & with & without \\
\hline Hydrophilicity $(\%)^{b}$ & 42.7 & 52.1 \\
\hline
\end{tabular}

a Manuscript in preparation.

b Hydrophilicity is defined as the percentage of hydrophilic amino acids; $($ Asx $+\mathrm{Thr}+\mathrm{Ser}+\mathrm{Glx}+\mathrm{Lys}+\mathrm{His}+\mathrm{Arg}) /($ total amino acid) $\times 100(\%)(7)$.

Tab. 3 Summary of significant correlations among excretions of several proteins in the urine of insulin-dependent diabetes mellitus patients ${ }^{\mathrm{a}}$.

\begin{tabular}{|c|c|c|c|c|}
\hline \multirow[t]{2}{*}{ rSs to } & \multicolumn{4}{|l|}{ Protein } \\
\hline & Biotinidase & Albumin & Total proteins & $\begin{array}{l}\text { N-Acetyl- } \\
\beta \text {-glucosaminidase }\end{array}$ \\
\hline Alanine & $0.667(\mathrm{p}<0.01)$ & No & No & No \\
\hline Duration & No & No & No & No \\
\hline Biotinidase & - & No & No & No \\
\hline Albumin & - & - & $0.794(\mathrm{p}<0.01)$ & No \\
\hline Total proteins & - & - & - & No \\
\hline Elevation of excretion ${ }^{\mathrm{c}}$ & Yes & No & No & ND \\
\hline
\end{tabular}

a Spearman's rank correlation coefficient (rS) was used. A probability value below 0.01 was considered to be significant. No; $\mathrm{p}>0.01$.

b ND; not determined. c Compared with the control level. Mann-Whitney's U test was used. A probability value below 0.01 was also considered to be significant or Yes. 
elevation of biotinidase and alanine is rare. To determine whether the simultaneous elevation of biotinidase and alanine excretion is possibly the earliest detectable manifestation of a predisposition to diabetic nephropathy, we re-inspected our urinary data of 21 insulin-dependent diabetes mellitus patients. It was found that 8 out of 21 patients $(38 \%)$ showed elevated excretion of both biotinidase and alanine. This value of $38 \%$ is similar to the cumulative risk of nephropathy $(30-40 \%)$.

\section{References}

1. Osterby Hansen R. Morphometric studies of the peripheral glomerular basement membrane in early juvenile diabetes. I. Development of initial basement membrane thickening. Diabetologia 1972; 8:84.

2. Osterby Hansen R. Early phases in the development of diabetic glomerulopathy. Acta Med Scand 1975; 1991: Suppl 574.

3. Walker JD, Close CF, Jones SL, Rafftery M, Keen H, Viberti $\mathrm{GC}$, et al. Glomerular structure in type-1 (insulin-dependent) diabetic patients with normo- and microalbuminuria. Kidney Int 1992; 41:741-8.

4. Bennett PH, Haffner S, Kasiske BL, Keane WF, Mögensen $\mathrm{CE}$, Parving $\mathrm{HH}$, et al. Screening and management of microalbuminuria in patients with diabetes mellitus: recommendations to the scientific advisory board of the national kidney foundation from an ad hoc committee of the council on diabetes mellitus of the national kidney foundation. Am J Kidney Dis 1995; $25: 107-12$.

5. Westberg NG, Michael AF. Human glomerular basement membrane: chemical composition in diabetes mellitus. Acta Med Scand 1973; 194:39-47.

6. Szabo A, Kenesei E, Korner A, Miltenyi M, Szucs L, Nagy I. Changes in plasma and urinary amino acid levels during diabetic ketoacidosis in children. Diabetes Res Clin Pract 1991; 12:91-7.

7. Oizumi J, Hayakawa K. Biotinidase and lipoamidase in guinea pig livers. Biochim Biophys Acta 1989; 991:410-4.

8. Pispa J. Animal biotinidase. Ann Med Exp Biol Fenn 1965; 43 Suppl 5:5-39.

9. Knappe J, Brümmer W, Biederbick K. Reinigung und Eigenschaften der Biotinidase aus Schweinenieren und Lactobacillus Casei. Biochem Z 1963; 338:599-613.

10. Nilsson L, Kagedal B. Lipoamidase and biotinidase activities in the rat: tissue distribution and intracellular localization. Eur J Clin Chem Clin Biochem 1994; 32:501-9.

11. Oizumi J, Hayakawa K. Liberation of lipoate by human serum lipoamidase from bovine heart pyruvate dehydrogenase. Biochem Biophys Res Commun 1989; 162:658-63.

12. Nilsson L, Ronge E. Lipoamidase and biotinidase deficiency: evidence that lipoamidase and biotinidase are the same enzyme in human serum. Eur J Clin Chem Clin Biochem 1992; 30:119-26.

13. Oizumi J, Hayakawa K. Enkephalin hydrolysis by human serum biotinidase. Biophys Biochim Acta 1991; 1074: 433-8.

14. Wolf B, Grier RE, Allen RJ, Goodman SI, Kien CL. Biotinidase deficiency: the enzymatic defect in late-onset multiple carboxylase deficiency. Clin Chim Acta 1983; 131:273-81.
Since preliminary studies suggest that early morning urine is as suitable as 24-hour urine for these studies, monitoring of these eight patients is expected to continue.

\section{Acknowledgements}

This work was supported by the Ministry of Health and Welfare, Japan. The authors are grateful to Drs. Masahiko Hirano and Kazuyuki Yoshikawa for their helpful discussions.
15. Baumgartner ER, Suormala T, Wick H, Bausch J, Bonjour JP. Biotinidase deficiency associated with renal loss of biocytin and biotin. Ann NY Acad Sci 1985; 447:272-87.

16. Kalayci Ö, Coskun T, Tokatli A, Demnir E, Erdem G, Güngör $C$, et al. Infantile spasms as the initial symptom of biotinidase deficiency. J Pediatr 1994; 124:193-4.

17. De Felice C, Hayakawa K, Tanaka T, Watanabe T, Hibi I, Kohsaka $T$, et al. High-performance liquid chromatographic assay for biotinidase activity in the human urine. J Liquid Chromatogr 1994; 17:2641-50.

18. Koivusalo M, Elorriaga C, Kaziro Y, Ochoa S. Bacterial biotinidase. J Biol Chem 1963; 238:1038-42.

19. Hayakawa K, Terentyeva EA, Tanae A, De Felice C, Tanaka $\mathrm{T}$, Yoshikawa $\mathrm{K}$, et al. Urinary protein and albumin determinations by high-performance gel-permeation chromatography. $\mathrm{J}$ Liquid Chromatogr 1995; 18:3955-68.

20. Hayakawa K, Oizumi J. Determination of lipoyllysine derived from enzymes by liquid chromatography. J Chromatogr 1989; 490:33-41.

21. Hayakawa K, De Felice C, Watanabe T, Tanaka T, Iinuma K, Nihei $\mathrm{K}$, et al. Determination of free $\mathrm{N}$-acetylneuraminic acid in human body fluids by high-performance liquid chromatography with fluorimetric detection. J Chromatogr 1993; 620:25-31.

22. Chaudry IH, Sayeed MM, Baue AE. Evidence for enhanced uptake of ATP by liver and kidney in hemorrhagic shock. Am J Physiol 1977; 233:83-8.

23. Amemiya $H$, Matsuo $T$, Motomiya $Y$, Sasaki H, Tomita E, Sada $\mathrm{M}$, et al. ATP level of effluent from preserved kidney by loading ATP- $\mathrm{MgCl}_{2}$. Igaku-no-ayumi (in Japanese) 1984; 128:371-2.

24. Bisschop A, De Jong L, Lima Costa ME, Konings WN. Relation between reduced nicotinamide adenine dinucleotide oxidation and amino acid transport in membrane vesicles from Bacillus subtilis. J Bacteriol 1975; 121:807-13.

\section{Received June 28/September 22, 1996}

Corresponding author: Dr. Kou Hayakawa, PhD, Endocrine and Metabolism Research Laboratory, National Children's Medical Research Center, 3-35-31 Taishido, Setagaya-ku, Tokyo 154, Japan 